\title{
Not only cigarettes - other culprits of lung cancer
}

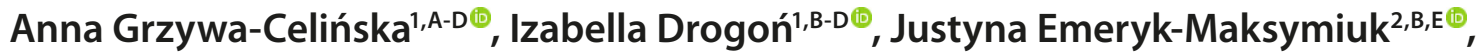 \\ Izabela Chmielewska ${ }^{1, A, E \oplus}$, Janusz Milanowski ${ }^{1, E-F} \oplus$ \\ ${ }^{1}$ Chair and Department of Pneumonology, Oncology and Allergology, Medical University, Lublin, Poland \\ ${ }^{2}$ Chair of Internal Medicine and Department of Internal Medicine in Nursing, Medical University, Lublin, Poland \\ A - Research concept and design, B - Collection and/or assembly of data, C - Data analysis and interpretation, \\ $D$ - Writing the article, E - Critical revision of the article, F - Final approval of article
}

Grzywa-Celińska A, Drogoń I, Emeryk-Maksymiuk J, Chmielewska I, Milanowski J. Not only cigarettes - other culprits of lung cancer. Ann Agric Environ Med. 2019; 26(4): 661-664. doi: 10.26444/aaem/109688

\begin{abstract}
Introduction. Before cigarettes became popular, lung cancer was an extremely rare disease, but currently it is the most common cause worldwide of cancer death in both genders. Therefore, it constitutes a huge epidemiological, diagnostic and socio-economic challenge around the world. In Poland, lung cancer is the second most common carcinoma in both men and women, and it is also the most prevailing cause of carcinous death. Undoubtedly, although smoking classical cigarettes is the strongest risk factor of developing the cancer, unfortunately it is not the only one.

Objective. The aim of this study was to present smoking-related factors, e.g. cigars, pipes, e-cigarettes or marijuana smoking, etiologically related to lung cancer incidence.
\end{abstract}

Key words

lung cancer, cigarettes, e-cigarettes

\section{INTRODUCTION}

Lung cancer was an extremely rare disease before cigarettes became popular, fashionable, generally available and massproduced. Although the use of tobacco has known since the Columbus era, smoking was not popular until the cigarette-wrapping machine was invented in the mid-1800s [1]. However, lung cancer was first observed more than a hundred years later. The surgeon Alton Ochsner recalls that in 1910, during his student years at Washington University, he participated in the autopsy of a patient with lung cancer, thinking that such a case might not happen again over the entire span of his career [2]. In 1912, a publication was released in which the author described all the cases of lung cancer reported around the world that were at that time available in the medical reference literature, and the grand total was only 374 [3]. In the 1920s, lung cancer was only diagnosed in $1 \%$ of all cancer patients, soon the incidence of lung cancer increased disproportionately compared to other cancers [4]. Simultaneously, the popularity of cigarettes increased in the mid 1960s from 100 cigarettes to 4,400 cigarettes per person per year [1]. At that time, scientists demonstrated a direct link between smoking and health deterioration [2]. Moreover, it was noted, that the risk of lung cancer correlated with the duration and magnitude of smoking. The prevalence of current cigarette smoking among adults declined from $42 \%$ in 1965 to $18 \%$ in 2012 . However, more than 42 million Americans still smoke [5]. In Poland, this number is significantly lower: 8 million Poles smoke every day [6]. Data from 2017 show that $24 \%$ of Poles smoke classical cigarettes every day and $2 \%$ smoke e-cigarettes. Tobacco in other forms (cigars, cigarillos, pipe tobacco or shags) is used by very few smokers [7].

Address for correspondence: Anna Grzywa-Celińska, Chair and Department of Pneumonology, Oncology and Allergology, Medical University, Lublin E-mail: acelin@op.pl

Received: 18.11.2018; accepted: 27.05.2019; first published: 14.06.2019
In the USA, more than 20 million people have died prematurely since the first Surgeon General's report in 1964 [8]. Currently, lung cancer is the most common worldwide cause of cancer death in both sexes, whereby more people die of lung cancer annually than as a result of colon, breast and prostate cancers combined [5].

In Poland, just after prostate and breast cancer, lung cancer is the second most common carcinoma in men and women [9], and is also the most prevailing cause of carcinous death among both genders. The incidence and mortality of lung cancer in males is twice as high as in females [10]. Since the 1990s, there has been a slow decline in the incidence and mortality of lung cancer among men, which is associated with the reduction in cigarette smoking. Among women, however, a constantly increasing morbidity and mortality rates are observed in this respect [11]. An older prediction suggests a significant decrease in mortality among middleaged men to the year 2025. Unfortunately, for the older population, an increase in mortality is forecasted. In the population of women, both middle-aged and those in an old age, the increase in mortality is expected to the year 2025 [12]. According to an age-period-cohort model, the incidence of lung cancer in the male population will remain on a high level during next two decades, but the incidence and mortality of lung cancer in women will still rise and stabilise not earlier than 2030 [10].

Clinically, lung cancer can be divided into two groups: non-small cell lung carcinoma and small-cell lung cancer. Among non-small cell lung carcinoma, three lung cancer subtypes are distinguished: squamous-cell carcinoma, adenocarcinoma and large-cell carcinoma. Currently, the severity stage is assessed according to strict rules based on the assessment of the tumour size, infiltration of the lymph nodes and the presence of distant metastases (TNM) [13]. This division determines the treatment options. In the group of non-small cell lung carcinoma at the I-IIIA severity stage, surgical treatment is of primary importance, and is sometimes 
complemented by radio- and/ or chemotherapy [14]. Smallcell lung cancer is extremely chemo- and radiosensitive, although despite treatment, prognosis in patients with this type of cancer remains rather grim due to the rapid spreading of the disease [15].

In recent years in Poland, new cutting-edge molecularlytargeted medications administered in the treatment of lung carcinoma have been registered and refunded: afatinib, erlotinib and gefetinib in patients with adenocarcinoma with an activating mutation in the EGFR gene, and in the case of T790M resistance mutation - osimertinib in the second line. Crizotinib in the second line of treatment in the presence of ALK gene rearrangement, nintedanib - an inhibitor of angiokinase with a triple action mechanism, blocking the activity of VEGFR, PDGFR and FGFR receptor kinases in combination with docetaxel following the failure of first line chemotherapy and relapse in patients with nonsmall cell lung adenocarcinoma [14, 16, 17]. As of May 2018 , government subsidies have covered immunotherapy - nivolumab in the second line of treatment in patients with squamous-cell carcinoma, and pembrolizumab in the first line of treatment of non-small cell carcinoma in the presence of PDL1 expression $>50 \%$. These medications are available to Polish patients in drug programmes once it has been established that a number of requirements specified by the Ministry of Health has been met $[14,17]$.

\section{STATE OF KNOWLEDGE}

The first scientific paper linking smoking with premature death appeared in 1938. The study by dr Raymond Pear revealed that smoking decreased life expectancy [18]. A decade later, studies conducted both in Europe and United States in the 1950s confirmed the role of smoking in cancer development [19-25]. For this reason, the disease is referred to as a civilization disease, and no one doubts the causal relationship between smoking and lung cancer incidence. The International Agency for Research on Cancer lists 30 agents with sufficient evidence to cause lung cancer [26]. Among these factors undeniably impacting lung cancer development the authors of the current study have chosen those which can be impacted by human behaviour.

Among other factors, the risk of lung cancer depends on the number of cigarettes smoked per day and the total duration of the addiction [27]. There are significant differences in the pattern of smoking cigarettes and that of smoking cigars, as well as the number of items smoked per day and the method of smoke inhalation. Several studies have been published which compare various tobacco products, such as cigars and cigarettes, and their respective impact on health. Cigars differ from cigarettes in size, tobacco content, and the production process itself. Cigarettes contain a mixture of different varieties of tobacco which are then wrapped in a thin tissue paper (cigarette tube). Cigars, on the other hand, consist of specially dried tobacco leaves which are then subjected to a fermentation process. Cigars are also characterised by a higher content of nitrates. They undergo chemical reactions that turn them into far more toxic nitrosamines. Cigar tobacco contains more carcinogenic substances than cigarette tobacco, e.g. NNN (N-Nitrosonornicotine), NNK (Nicotinederivednitrosamineketone, 4- (methylnitrosamino)-1-(3pyridyl)-1-butanone). Compared to cigarette smoke, cigar smoke contains more nitric oxide, ammonia, nitrosamines and $\operatorname{tar}[28,29]$.

Due to the size of a cigar and the duration of smoking, cigar smokers are more exposed to toxic substances than cigarette smokers [29], but both groups of smokers show a similar risk of lung cancer incidence [30].

Pipe smoking is also one of the recognised causes of lung cancer [30, 31]. Difficulties in estimating the risk of disease incidence among pipe smokers compared to cigarette smokers result from many differences in the way tobacco is used in those two cases: the number of grams of the tobacco smoked, the age at which one starts smoking, the duration of the substance dependence, smoke inhalation method, as well as the quality of the study: exclusive inclusion of pipe smokers in the study and the length of observation. The results of the study performed by Lubin et al. [31] undoubtedly indicate an increased risk of lung cancer incidence in pipe smokers compared to non-smokers, while a lower risk of carcinoma incidence was observed in pipe smokers when compared to cigarette smokers. An analysis of the studies considering the above aspects and the cumulative dose of tobacco indicates a similar risk of lung cancer in groups of people smoking cigarettes, cigars and pipes [30], which has been additionally confirmed by research from the Scandinavian region $[32,33]$.

According to data obtained in 2014 from the Central Statistical Office of Poland (GUS), one in 20 persons has consumed marijuana at least once in their life [34]. These data are probably underestimated. The European Monitoring Centre for Drugs and Drug Addiction presents the following data in the Poland Country Drug Report 2017: 9.8\% of young adults (aged 15-34 years) used cannabinoids in 2015, therefore, currently it is the most commonly used illegal substance in Poland [35].

Unlike cigarettes which contain nicotine, the addictive substance in marijuana is tetrahydrocannabinol (THC). The smoke produced by burnt marijuana contains many substances which are also present in cigarette smoke; these substances have a proven carcinogenic effect on the epithelial cells of the airways. These are nitrosamines and polycyclic aromatic hydrocarbons (benzopyrene, benzoanthracene) which cause mutations in the $p 53$ gene [36].

The results of several studies on the association of marijuana with lung cancer are not conclusive $[37,38]$. This is due to such factors as the difficulty in isolating a representative group for research, because smoking marijuana often coexists with smoking cigarettes. Furthermore, the observation time of such a cohort should be long enough in view of the young age of marijuana smokers.

To date, few scientific reports have been released regarding the impact of e-cigarettes on the process of carcinogenesis. An electronic cigarette is a device that generates a vapour by means of heating a specially dedicated liquid (e-liquid), which is then inhaled into the respiratory tract. E-cigarettes are manufactured by different companies and have appear in many different forms: from those deceptively reminiscent of cigars or traditional cigarettes, to pipes and others which resemble pens. Depending on the brand, the composition of e-liquids differs significantly. In the European Union, it is subject to restrictions delineated in the Directive of the European Parliament and the EU Council of 3 April 2014, which sets the maximum amount of nicotine in $1 \mathrm{ml}$ of e-liquid at the level of $20 \mathrm{mg}$; therefore providing the same amount of nicotine as from smoking one cigarette [39]. This 
liquid is usually a blend of purified nicotine, propylene glycol and glycerol. It often also contains various aromas, e.g. fruit, menthol, chocolate, or mint.

The e-cigarette vapour also contains carcinogens, e.g. formaldehyde, acetaldehyde, N'-nitrosonornicotine (NNN) and 4-(methylnitrosamine)-1- (3-pyridyl)-1-butanone (NNK), and the heavy metals: cadmium, nickel and lead. Their content, however, is $9-450$ times lower than in the case of a traditional cigarette smoke [40]. E-cigarettes are often an alternative for cigarette smokers (the lesser evil); however, it cannot be claimed that they are neutral to the smoker's health. While there are scientifically proven and safe ways to help quit smoking, it seems inappropriate to recommend switching from traditional cigarettes to the electronic variety - a far better option would be to encourage smokers to quit smoking altogether. It is a known fact that a successfully implemented nicotine replacement therapy does not correlate with the occurrence of lung cancer [41], hence for the time being, it is safer and more beneficial to the patient's health than smoking e-cigarettes. In view of the growing sales of electronic cigarettes and high interest in their use, it can be assumed that more research will surface regarding their impact on health, but long-term observation and research are needed to prove the possible carcinogenic effects of the e-cigarette vapour.

\section{CONCLUSIONS}

Lung cancer constitutes a huge epidemiological, diagnostic and socio-economic challenge, both in Poland and worldwide. As outlined above, lung carcinoma is the most common disease caused by cigarette smoking; however, there are many other factors that may affect the development of this medical condition, such as smoking other tobacco products discussed above. The growing popularity of e-cigarettes in Poland, which are often advertised as safe substitutes for traditional tobacco products, generates the need to supply reliable clinical data on the subject. The increasing use of marijuana (especially among young adults) requires epidemiological surveillance, because, as of today, the long-term effects of marijuana smoking are not known, and its connection with lung cancer has not been explicitly confirmed (or excluded). The shifting trends in the use of tobacco products, as well as the smoking of their nicotine substitutes, necessitate additional research into the impact of these factors on the risk of lung cancer occurrence. Awareness of the existence of modifiable threats constitutes the first step in an effective prevention of this deadly disease.

\section{REFERENCES}

1. Dela Cruz CS, Tanoue LT, Matthay RA. Lung cancer: epidemiology, etiology, and prevention. Clin Chest Med. 2011; 32(4): 605-644.

2. Ochsner A. Corner of history: my first recognition of the relationship of smoking and lung cancer. Prev Med. 1973; 2: 611-614.

3. Adler I. Primary malignant growths of the lungs and bronchi. New York: Longmans, Green, and Company, 1912.

4. Hruby AJ, Sweany HC. Primary carcinoma of the lung: with special reference to incidence, early diagnosis and treatment. Arch Intern Med. 1933; 52(4): 497-540.

5. American Cancer Society; Key Statistics for Lung Cancer 2018; https://www.cancer.org/cancer/non-small-cell-lung-cancer/about/ key-statistics.html
6. Zatoński W, Zatoński M, Janik-Koncewicz K, Połtyn-Zaradna K, Wijatkowska K, Marciniak A. Hundred years of cigarette smoking in Poland: three phases of the tobacco epidemic. J Health Inequal. 2017; 3(2): 118-122. doi:10.5114/jhi.2017.74200

7. Trząsalska A, Staszyńska M, Krassowska U. Raport z ogólnopolskiego badania ankietowego na temat postaw wobec palenia tytoniu. [Report of polish nationwide survey on attitudes towards cigarette smoking]. https:/gis.gov.pl/wp-content/uploads/2018/04/Postawy-Polaków-dopalenia-tytoniu-Raport-2017.pdf] (Polish)

8. U.S. Department of Health and Human Services. The Health Consequences of Smoking: 50 Years of Progress. A Report of the Surgeon General. Atlanta, GA: U.S. Department of Health and Human Services, Centers for Disease Control and Prevention, National Center for Chronic Disease Prevention and Health Promotion, Office on Smoking and Health, 2014. Printed with corrections, January 2014.

9. Wojciechowska U, Czaderny K, Ciuba A, Olasek P, Didkowska J. Cancer in Poland in 2016, Polish Ministry of Health, Warsaw 2018.

10. Czaderny K. Uwarunkowania skłonności do palenia papierosów. Wyniki modelowania równań strukturalnych [Conditioning of propensity to smoking cigarettes. The results of structural equations modeling]. Studia Demograficzne 2017; 171(1): 49-69 (Polish).

11. Krajowy Rejestr Nowotworów (KRN): Nowotwory złośliwe opłucnej i płuca (C33-34) [National Cancer Registry: Malignant Neoplasms of the Lung and Pleura (C33-34)]. http://onkologia.org.pl/nowotworyzlosliwe-oplucnej-pluca-c33-34/ (Polish).

12. Didkowska J, Wojciechowska U, Zatoński W. Prediction of cancer incidence and mortality in Poland up to the year 2025, Warsaw 2009.

13. Jassem J, Wysocki WM. Klasyfikacja TNM (2017) w niedrobnokomórkowym raku płuca [TNM classification (2017) in non-small cell lung carcinoma] https://www.mp.pl/interna/chapter/B16.II.3.14.1.Tab. 3.16-1 (Polish).

14. Ministerstwo Zdrowia: Leczenie niedrobnokomórkowego raka płuca [Polish Ministry of Health: Treatment of non-small cell lung cancer]. https://www.gov.pl/zdrowie/choroby-onkologiczne (Polish).

15. Crivellari G, Monfardini S, Stragliotto S, Marino D, Aversa SM. Increasing chemotherapy in small-cell lung cancer: from dose intensity and density to megadoses. Oncologist. 2007; 12(1): 79-89.

16. Hirsch FR, Scagliotti GV, Mulshine JL, Kwon R, Curran W, Wu YL, Paz-Ares L. Lung cancer: current therapies and new targeted treatments Lancet. 2016; 389(10066): 299-311. doi: 10.1016/S0140-6736(16)30958-8.

17. Ministerstwo Zdrowia: Leczenie niedrobnokomórkowego raka płuca z zastosowaniem afatynibu i nintedanibu [Polish Ministry of Health: Treatment of non-small cell lung cancer with afatynib and nintedanib]. https://www.gov.pl/zdrowie/choroby-onkologiczne (Polish).

18. Pearl R Tobacco smoking and longevity. Science. 1938; 87(2253): 216217. doi: 10.1126/science.87.2253.216.

19. Doll R, Hill AB. Smoking and carcinoma of the lung; preliminary report. Br Med J. 1950; 2(4682): 739-748.

20. Doll R. Lung cancer and other causes of death in relation to smoking; a second report on the mortality of British doctors. Br Med J. 1956; 2(5001): 1071-1081.

21. Smoking and Health: Report of the Advisory Committee to the Surgeon General of the Public Health Service, U.S. Department of Health, Education, and Welfare, 1964, https://profiles.nlm.nih.gov/ps/access/ nnbbmq.pdf.

22. Wynder EL, Graham EA. Etiologic factors in bronchiogenic carcinoma with special reference to industrial exposures; report of eight hundred fiftyseven proved cases. AMA Arch Ind Hyg Occup Med. 1951; 4(3): 221-235.

23. Lickint F. Bronchial carcinoma in non-smokers. Munch Med Wochenschr. 1954; 96(47): 1366-1369 (German).

24. Ochsner A, DeBakey M. Carcinoma of the lung. Arch Surg. 1941; 42(2): 209-258.

25. Ochsner A, Debakey M. Primary pulmonary malignancy: treatment by total pneumonectomy; analysis of 79 collected cases and presentation of 7 personal cases. Ochsner J. 1999; 1(3): 109-125.

26. International Agency for Research on Cancer; IARC Monographs on the Identification of Carcinogenic Hazards to humans; https://monographs. iarc.fr/agents-classified-by-the-iarc

27. Doll R, Peto R, Boreham J, Sutherland I. Mortality in relation to smoking: 50 years' observations on male British doctors. BMJ. 2004; 328 (7455): 1519. doi: 10.1136/bmj.38142.554479.AE

28. Baker F, Ainsworth SR, Dye JT, Crammer C, Thun MJ, Hoffmann D et al. Health risks associated with cigar smoking. JAMA. 2000; 284(6): 735-740.

29. National Cancer Institute; Cigar Smoking and Cancer; https://www. cancer.gov/about-cancer/causes-prevention/risk/tobacco/cigars-factsheet 
30. Boffetta P, Pershagen G, Jöckel KH, Forastiere F, Gaborieau V, Heinrich J et al. Cigar and pipe smoking and lung cancer risk: a multicenter study from Europe. J Natl Cancer Inst. 1999; 91(8): 697-701.

31. Lubin JH, Richter BS, Blot WJ. Lung cancer risk with cigar and pipe use. J Natl Cancer Instit. 1984; 73(2): 377-381.

32. Carstensen JM, Pershagen G, Eklund G. Mortality in relation to cigarette and pipe smoking: 16 years' observation of 25000 Swedish men. J Epidemiol Commumity Health; 1987; 41: 166-172.

33. Damber LA, Larsson LG. Smoking and lung cancer with special regard to type of smoking and type of cancer. A case-control study in north Sweden. Br J Cancer. 1986; 53(5): 673-681.

34. Główny Urząd Statystyczny, Zdrowie i zachowanie zdrowotne mieszkańców Polski w świetle Europejskiego Ankietowego Badania Zdrowia (EHIS) 2014 r. [Central Statistical Office of Poland, Health and health behaviour of inhabitants of Poland in the light of European Interview Health Survey (EHIS)], Warszawa, 1 grudnia 2015. https://stat. gov.pl/files/gfx/portalinformacyjny/pl/defaultaktualnosci/5513/10/1/1/ zdrowie_i_zachowania_zdrowotne_mieszkancow_polski_w_swietle_ badania_ehis_2014.pdf

35. European Monitoring Centre for Drugs and Drug Addiction (2017), Poland, Country Drug Report 2017, Publications Office of the European Union, Luxembourg. http://www.emcdda.europa.eu/

36. Denissenko MF, Pao A, Tang M, Pfeifer GP. Preferential formation of benz[a]pyrene adducts at lung cancer mutational hotspots in P53. Science. 1996; 274: 430-432.
37. Barsky SH, Roth MD, Kleerup EC, Simmons M, Tashkin DP Histopathologic and molecular alterations in bronchial epithelium in habitual smokers of marijuana, cocaine, and/or tobacco. J Natl Cancer Inst. 1998; 90(16): 1198-1205.

38. Melamede R. Cannabis and tobacco smoke are not equally carcinogenic. Harm Reduct J. 2005; 18(2): 21.

39. Directive 2014/40/EU of the European Parliament and of the Council of 3 April 2014 on the approximation of the laws, regulations and administrative provisions of the Member States concerning the manufacture, presentation and sale of tobacco and related products and repealing Directive 2001/37/EC Text with EEA relevance.[Dyrektywa Parlamentu Europejskiego i Rady 2014/40/UE z dnia 3 kwietnia 2014 r. w sprawie zbliżenia przepisów ustawowych, wykonawczych i administracyjnych państw członkowskich w sprawie produkcji, prezentowania i sprzedaży wyrobów tytoniowych i powiązanych wyrobów oraz uchylająca dyrektywę 2001/37/WE] https:// eur-lex.europa.eu/legal content/PL/TXT/?uri=celex\%3A32014L0040] (polish).

40. Goniewicz ML, Knysak J, Gawron M, Kosmider L, Sobczak A, Kurek J, et al. Levels of selected carcinogens and toxicants in vapour from electronic cigarettes. Tob Control. 2014; 23(2): 133-139. doi: 10.1136/ tobaccocontrol-2012-050859

41. Murray RP, Connett JE, Zapawa LM. Does nicotine replacement therapy cause cancer? Evidence from the Lung Health Study. Nicotine Tob Res. 2009; 11(9): 1076-1082. doi: 10.1093/ntr/ntp104

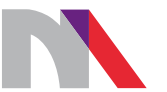

\section{Ministry of Science and Higher Education}

Republic of Poland

Generation of the DOI (Digital Object Identifier) - task financed under the agreement No. 618/P-DUN/2019 by the Minister of Science and Higher Education 